Article

\title{
Alternative Media and the Notion of Anti-Systemness: Towards an Analytical Framework
}

\author{
Kristoffer Holt \\ Department of Mass Communication and Media, Gulf University for Science and Technology (GUST), Mubarak Al-Abdullah \\ Area/West Mishref, Kuwait; E-Mail: Holt.A@gust.edu.kw
}

Submitted: 6 March 2018 | Accepted: 27 June 2018 | Published: 8 November 2018

\begin{abstract}
A range of alternative media outlets focusing on criticizing immigration politics and mainstream media have emerged in Sweden in recent years. Although they have quite different ideological profiles, they share a clear and critical focus on immigration and mainstream journalistic representations of reality. Their message is that mainstream media conceal or distort information about negative societal and cultural consequences of immigration and that mainstream journalists have teamed up with the political elites and engage in witch-hunts of critics, while ignoring abuses by those in power. Such media outlets (especially online participatory media) need to be analyzed in the light of their position as self-perceived correctives of traditional media. There has been a remarkable surge of alternative media in Sweden with these traits in common during the past few years, and it is important to be able to discuss these media together as a phenomenon, while at the same time taking their differences into account. In relation to this, I argue that the notion of anti-systemness is useful in discussions of the impact these alternative media may (or may not) have on public discourse. In the article, I present a matrix that distinguishes between different types of anti-systemness: ideological anti-systemness and relational antisystemness. The article therefore mainly presents a theoretical argument, rather than empirical findings, with the aim of pointing to a way forward for research about alternative media.
\end{abstract}

\section{Keywords}

alternative media; anti-systemness; counter-publics; ICAM; immigration; journalism; media distrust; polarization

\section{Issue}

This article is part of the issue "News and Participation through and beyond Proprietary Platforms in an Age of Social Media", edited by Oscar Westlund (Oslo Metropolitan University, Norway) and Mats Ekström (University of Gothenburg, Sweden).

(C) 2018 by the author; licensee Cogitatio (Lisbon, Portugal). This article is licensed under a Creative Commons Attribution 4.0 International License (CC BY).

\section{Introduction}

Not long ago, there were great expectations among media scholars as well as public intellectuals and debaters about how participatory aspects of journalism and news production, especially through social media and the web 2.0, could change public discourse in positive, more inclusive and, therefore, democratically beneficial ways (Deuze, Bruns, \& Neuberger, 2007; Jenkins, 2008; O'Reilly, 2005). Giving the grassroots voice and visibility was especially pointed out as a promising aspect of participatory and citizen journalism (Domingo et al., 2008). Now, after more than a decade of web 2.0 reality, there seems to be more talk of populism than grassroot par- ticipation and a growing concern about fake news, hatespeech and propagandistic micro-targeting in online participatory channels (Anderson \& Revers, 2018; Quandt, 2018). Alternative and participatory media are increasingly described as threats to the system, rather than as promising and reinvigorating reformers in a time of waning enthusiasm for democratic engagement. After Brexit and Donald Trump's unexpected victory in the American presidential election of 2016, analysts and researchers were collectively left scratching their heads, wondering what mistakes were made in the many analyses and predictions that preceded both elections.

In the self-examination that followed, many explanatory models emerged. One in particular has been re- 
peated again and again as a mantra: the gap between societal elites and the "Average Joe" must have become so great that the elites lack contact with common people and fail to understand how they think, and what problems really concern them. American journalists seemed shocked that Trump's aggressive rhetoric targeting "mainstream media" seemed to have resonated with a large number of people (Barbaro, 2016). Even more unpleasant to many journalists was the insight that alternative news sites such as Breitbart News, which supported Trump actively during the campaign, proved to have an underestimated reach despite its reputation as a dubious playground for various factions of the American so called "alt-right". Clinton's campaign also contributed, paradoxically, to the impact of the "alt-right" by calling it out as a major opponent (Gourarie, 2016).

The fact that journalists in the major newspapers and the radio and TV channels seemed to be regarded by many citizens as part of the establishment and found themselves accused of being corrupt, fettered, leftist and back-tied by pledged allegiances to political correctness came as a cold shower for many who had actually seen themselves as "watchdogs" in relation to power, as the people's advocates.

A common denominator among many on the "right" side of the ideological spectrum (far-right as well as rightwing populists and many moderate conservatives) is that their narratives often criticize "mainstream media" for being biased in favor of liberal/leftist perspectives, uncritical of those in power and out of touch with ordinary people. At the same time, a host of "alternative media", often with a focus on criticism of liberal immigration politics and a harsh tone against mainstream media, has become an important factor in public discourse in many western countries. This article is about how such politically and ideologically driven alternative media affect media as a system for public discourse throughout the western world.

It is becoming more and more evident that alternative right-wing media are increasingly relevant in the field of political, as well as ideological and cultural communication (Nagle, 2017). It is also clear that the rapid emergence of phenomena such as the so called "alt-right" online movement has given rise to surprise and confusion (Gourarie, 2016). I argue that some of this confusion, at least in terms of scholarly attempts to come to grips with it, has to do with a discrepancy between the dominant theories about alternative media and alternative media as they actually are.

Scholarly work about alternative media has in essence taken its cue from Gramsci and the notion of hegemony. Alternative media is in such a setting seen as a liberating force, empowering and giving voice to groups who suffer from marginalization in the hegemonic discourse of mainstream "bourgeois" media. Historically, the phrase "mainstream media" has been used mostly by left-wing debaters, such as Noam Chomsky (1997) and by media scholars; "alternative media" has long been considered the embodiment of a dream about giving ordinary citizens a way of speaking back to power (see, e.g., Atton, 2015; Bailey, Cammaerts, \& Carpentier, 2007; Lievrouw, 2011; Pajnik \& Downing, 2008). Much research has therefore focused on activist uses of media (Penney \& Dadas, 2014). Researchers have been reluctant to talk about right-wing populist, far-right activists or conservative criticism of the "politically correct" and "leftist" mainstream media using existing theoretical frameworks, although there are exceptions. Downey and Fenton (2003, p. 197), for example, pointed out that "it would be clearly a mistake to ignore the construction of right-wing counter-publics", and both Downing, Ford, Gil and Stein (2001) and Atton (2006) have approached these phenomena, albeit with a specific focus on the extreme-right and with a normative stance. In this article, I view alternative media in light of the current media landscape, marked by polarization and culture wars (Nagle, 2017). I argue that it would be beneficial if theoretical assumptions about alternative media were valid, irrespective of the media's ideological orientation. It is also necessary to view opposing media channels, especially online participatory media in the light of their position as self-perceived correctives of traditional mainstream media, presenting alternative interpretations of political and social events. This motive is particularly apparent in alternative media that is critical of immigration politics and the perceived threat of Islamization of western countries-although the main focus and level of "anti-systemness" (Capoccia, 2002) varies greatly between different actors. While some can be extreme and incite to violence, others can be moderate and reasonable (Holt, 2016a). Some are outspokenly anti-system, others are not-but may still have a polarizing effect on the media landscape. Yet others may show no signs of anti-systemness.

Thus, this article seeks to nuance the discussion of how alternative media-especially those with ideologi$\mathrm{cal} /$ political agendas that clash with predominant values of the mainstream media-affect public discourse. I introduce a theoretical distinction between two different types of anti-systemness: ideological and relational. This framework is designed to work on any alternative media, regardless of political/ideological orientation, but is exemplified using Swedish alternative media that are critical of the country's immigration policy, building on insights from previous research (Holt, 2016a). This framework is important, because it enables a focused discussion of specific cases and makes it easier to identify alternative media that qualify as "anti-system" and those that do not. The argument is in essence theoretical with the aim of informing and inspiring future research.

\subsection{Media Distrust and Alternative Media}

Expressions of skepticism and suspicion of mainstream media are heard in many places throughout Europe and the USA these days. "Lügenpresse" ["the lying press"] 
was, for example, a common slogan in the PEGIDA marches in Dresden, Germany, and elsewhere (Haller \& Holt, 2018; Holt \& Haller, 2017). Hegemonic mainstream media are seen to conceal or distort information that does not fit the "politically correct" agenda. In Sweden, right-wing movements, ranging from parties such as the Sweden Democrats (SD) to more extreme think-tanks such as Motpol.nu, raise criticism along these lines, although their approaches and lines of reasoning vary greatly (Holt, 2016a). They voice media skepticism, distrust and criticism in what might be termed immigrationcritical counter-publics (Downey \& Fenton, 2003). Tsfati (2003) defines media skepticism as a sense of "alienation and mistrust toward the mainstream media". It involves the "feeling that journalists are not fair or objective in their reports about society and that they do not always tell the whole story", and that mainstream journalists "will sacrifice accuracy and precision for personal and commercial gains" (Tsfati, 2003, p. 67).

This is hardly to suggest that media criticism is dangerous or bad in itself. However, if certain groups in society choose to abstain from participation in the regular mainstream platforms of public discourse (which are normally considered as the commons, the "agora") and instead entrench themselves in counter-publics where discourses of alienation and mistrust in conventional democratic channels are fostered and amplified, it can be problematic from a democratic perspective (Kobayashi \& Ikeda, 2009; Sunstein, 2007). Firstly, it reveals that some people feel that they cannot participate on equal terms and choose alternative platforms outside the conventional news providers. Secondly, it can become an obstacle to deliberation between conflicting parties, which seriously challenges the democratic system.

The Swedish example is especially interesting. Support for the right-wing populist party, the SD, was long significantly lower than the support for similar parties in neighboring countries. But since the 2010 election, when they first received enough votes to be represented in parliament, support for the party has grown rapidly (from $5.7 \% 2010$ to $14 \% 2015$ and in some recent polls around $20 \%$ ). During this period, the number and nature of scandals reported in the media about members of this party outnumber those involving members of other parties by far (Ekman \& Widholm, 2014). SD have built a lot of their rhetoric around framing themselves as henpecked outsiders, without a fair chance in mediated political debates (Hellström \& Nilsson, 2010). The claim is that mainstream media has put a lid on the debate about immigration, ostracizing critical opinions (Holt, 2017). Rhetorically, this has worked well for SD, since much criticism of the party has been easily explained away with references to "media bias". After the ruling Social Democratic party in Sweden suddenly decided to take measures to radically reduce the high number of asylum seekers during the 2015 migrant crisis, a growing number, even among mainstream journalists, have argued that there is some truth to the claim that immigration has been off limits for serious discussion in the Swedish public sphere for fear of being labelled racist (Truedson, 2016).

If massively negative media-coverage in the mainstream channels has not hampered the increasing support for SD, it may be because there are other voices available which play an important, and perhaps underestimated role in public discourse. There are indications that immigration-critical alternative media (ICAM) in Sweden have a significant reach (Borgs, 2015; Newman, Fletcher, Kalogeropoulos, Levy, \& Kleis Nielsen, 2018). Survey data presented in the Reuters Institute Digital News Report (Newman et al., 2018) reveal that each of the four major ICAM in Sweden reaches "around one tenth of the Swedish online population on a weekly basis" (Newman et al., 2018). Their readers are also clearly more right-wing oriented than readers of the most influential mainstream media in Sweden. Furthermore, the study reveals, their readers express much less trust in regular news-reporting than others (Newman et al., 2018). These sites (Fria Tider, Nyheter Idag, Ledarsidorna, Samhällsnytt and Nya Tider) are regularly described in mainstream media as a threat to the democratic system, as purveyors of hate and generally troll-friendly. While this might be true of some ICAM, it hardly holds for all of them. The problem is that they tend to be lumped together and treated as one coordinated entity-and are often generalized as extremists. Anti-mainstream media rhetoric is particularly targeted and described as a threat to freedom of speech. Some actors, such as the now defunct YouTube channel, Granskning Sverige (Burman, 2017), actually threaten and target individual journalists; others merely publish critical opinions and analysis. It is therefore important to distinguish between alternative media that actually display anti-system tendencies and those who do not. Being critical of mainstream news is not the same thing as promoting extreme agendas. It is crucial for scholars to make this distinction. Why are some groups angry with the "Lügenpresse"? How does their anger affect public discourse on a general level? Is this mistrust a threat to the democratic system, and does it pose a danger to free media? If so, in what ways?

I will not be able to answer these questions here, but I do propose a framework that I believe will aid the pursuit of the answers.

\subsection{Alternative Media}

The term "alternative media" used in scholarly research (see, e.g., Atkinson \& Leon Berg, 2012; Rauch, 2015) aims -in broad terms - at media that challenge the established channels and put forward alternative approaches and perspectives that contradict or diverge from an experienced dominant discourse in the mainstream media (Atton, 2015; Leung \& Lee, 2014). The term does not require any particular focus but refers to all types of media that are created and run in opposition to what is perceived as a dominant discourse in traditional media. Typically, according to Leung and Lee (2014, 
p. 341), "such alternative media often jettison the conventional journalistic norms of objectivity and impartiality to espouse specific political views".

Talking about alternative media will be confusing unless we classify them in a way that signals an orientation that separates them from other types of alternative media. The focus in this article rests specifically on alternative media that show a fundamentally (more or less pronounced) critical attitude towards the Swedish immigration policy and its consequences as well as towards the media establishment (Holt, 2016a, 2017). In Sweden, in recent years, the term has been associated specifically with immigration-critical media, characterized by an emphatically oppositional stance vis-à-vis both the political and the media establishment. In the Swedish context, the term "alternative media" refers to:

A self-assumed term that signals an opposition to traditional media ("old media"), which many of the writers in this field regard as failing to report properly on important societal issues, for example, by avoiding reporting on social problems related to immigration. (Holt, 2016b, my translation)

The term "alternative media" is here somewhat problematic as such a classification is imprecise and implicitly could give the reported media the status of equivalent, "interchangeable" alternatives to established journalistic media. This could of course be problematic, given the huge difference regarding the conditions, ambitions and resources that exist between the "alternative" and the "mainstream". On the other hand, several of the people interviewed by Holt (2016a) registered some objection to the term because it can be interpreted as a way to impose a state of permanent exclusion. That is, the term "alternative" emphasizes and consolidates a position beyond the mainstream, beyond the pale.

Alternative media are relevant because their existence and working methods can affect the public conversation and the rest of the media landscape and hence the conditions for opinion formation and news consumption. Also, epistemologically, they often pose a challenge to mainstream media, since they implicitly, and often explicitly, challenge mainstream media's "fake news", while at the same time, more often than not, they have very limited resources to perform investigative research on their own and for the most part rely on reports from mainstream media for what they write about (Holt, 2016a). What is lacking in research, however, is a good way of approaching the study of this field that allows for a discussion of specific alternative media (regardless of their ideological/political leanings) as a phenomenon while still taking the wide variety within this type of alternative media in to account. Now, how might we approach this field of study in a manner that both views alternative media as a phenomenon in itself and makes distinctions among the various media? In my effort to answer this question I have taken inspiration from theories about anti-system parties (Capoccia, 2002). Similar to how a country's political landscape is affected when a new and ideologically controversial party wins support, the media landscape is inevitably affected when new media that promote standpoints considered by others as controversial enter the arena and win an audience. If these media, like some parties, can represent positions that are harshly critical of the political establishment and the elites and at the same time express opinions that are very far from other actors in the arena, some specific problems arise. The effects of such changes are often described in terms of increasing political polarization and challenges to the legitimacy of the established political system (Sartori, 2005). Just as it is possible to talk about such types of parties' influence on the political arena, media that display similar features (anti-establishment rhetoric, a message that undermines confidence in the current order and positions far from the rest of the media actors), contribute to increased polarization in the public debate conducted through media in a society.

As for the Swedish ICAM, we can see that there are major differences in how the various actors relate and positions themselves to other media actors and to what extent their legitimacy is challenged (Holt, 2016a). Therefore, it is necessary to distinguish between the different types of anti-systemness in a more elaborated manner.

\section{Different Types of Anti-Systemness}

As stated above, these alternative media channels need to be analyzed in the light of their position as a perceived corrective of traditional media and of constrained public discourse. This is in line with an anti-system line of thought (Capoccia, 2002). Anti-system attitudes can occur both to the Left and the Right, and Capoccia (2002, drawing on Sartori, 1976), distinguishes between relational anti-systemness (how a party positions itself in relation to other parties and vice versa) and ideological anti-systemness (whether or not the ideological foundation of the party includes an agenda to alter or destroy the system; Capoccia, 2002, p. 24). It is thereby possible to discuss different types of anti-systemness and to widen the definition beyond strictly anti-democratic movements. Many European parties that Mudde (2014, p. 217) calls "populist radical right parties (PRRPs)", for example, are not ideologically anti-democratic, but can still show signs of relational "anti-systemness", placing them in the category "polarizing parties" according to Capoccia (2002). I argue that such a distinction is also relevant to the sphere of alternative media.

ICAM position themselves as contenders to, or rebels against mainstream media's norms and ways of working-for example, ethical codes stipulating caution when reporting on crimes committed by immigrants (see, Pressens Samarbetsnämnd, 2001). Because of such restraints, mainstream media is construed as a mouthpiece of the political establishment rather than as watchdogs in relation to politicians. Epistemologically, ICAM also posi- 
tion themselves as exposers of mainstream media's "fake news". As a response to this there are now a number of alternative media that present other interpretations of reality, and may report in ways considered unorthodox by journalists in the mainstream. There is reason to examine whether they show signs of anti-systemness and, if so, in what ways. These media, like anti-system parties, display anti-system characteristics to different degrees and for various reasons: some are clearly antisystem in the ideological sense while others who are not still appear to be anti-system in the relational sense (see Figure 1) by virtue of the polarizing effect they have in relation to other media outlets. Furthermore, some ICAM might not show any signs of anti-systemness, relational or ideological, which is also important to be able to point out. The differences between these types of antisystemness are illustrated below in The Alternative Media Anti-systemness Matrix (Figure 1).

Ideological anti-systemness refers to the degree of antagonism and distrust displayed by actors in the specific alternative media toward mainstream media and their institutions within the established media system of a nation. Capoccia (2002) explains Sartori's definition of ideological anti-systemness as abiding by a belief system that "does not share the values of the political order within which it operates" (Capoccia, 2002, p. 14). In other words, it is a stance that would abolish the system of governance as a whole. Obviously, this represents a quite extreme position and would in relation to media mean a vision of a completely different media system. Ideological anti-systemness might be studied through self-descriptions, interviews and content analysis of material available through the specific alternative media (blog posts, pods, articles, YouTube clips, etc.). In order to fulfil this criterion, it must be clear that the view taken on mainstream media is clearly antagonistic and excludes any hope of change or remedy of the perceived ills. One example of such an outspoken position in the Swedish case, as identified by (Holt, 2016a), is the YouTube channel, Granskning Sverige, which regularly interviewed journalists and politicians in a provocative and confrontative manner and recorded the interviews secretly and published them (often in a tendentiously edited version). The channel clearly displays signs of ideological anti-systemness since they generally attacked and targeted mainstream journalists and called for the whole system to be abolished and replaced.

Relational anti-systemness refers to media that may, but do not necessarily meet the criteria of ideological anti-systemness, but still have an effect on other media. Capoccia (2002, p. 14) outlines three attributes of relational anti-systemness:

- "Distant spatial location from neighboring parties" (meaning that their views are far from even those who could be described as closest to them), which in turn leads to:

- "Low coalitional potential", which in turn entails:

- "Outbidding propaganda tactics/delegitimizing messages".

As for parties, these three dimensions are applicable to alternative media. Although some are not ideologically anti-system, they may have an impeding and/or polarizing effect on the media environment as a whole, similar to the effect some parties have on the party system when other actors position themselves strongly against them, for example through a "cordon sanitaire" or quarantine, or by refusing to participate in the same public debates because their views are considered unacceptable. Their conduct can also change or erode the standards for what is considered acceptable, especially if there is a high demand for the type of content they offer. In the Swedish case, the unique selling point of ICAM is in several cases that they provide information about the ethnicity of criminal offenders (which is generally omitted in mainstream

Relational anti-systemness

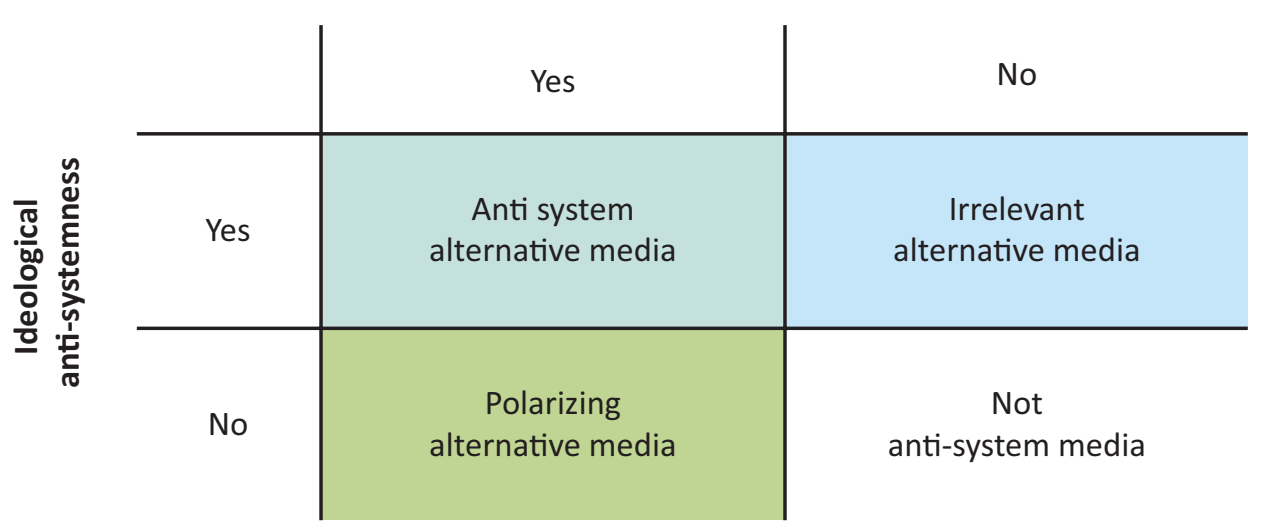

Figure 1. The Alternative Media Anti-systemness Matrix. Based on Capoccia's (2002) typology of "anti-system parties". The $2 \times 2$ matrix displays a typology of alternative media and their different forms of anti-systemness (or lack thereof) in relation to traditional media's positions, norms and ways of working. 
news). If this type of content is attractive to readers, and hence constitutes a serious competitive advantage for ICAM in relation to mainstream media, it might lead to altered praxis in the mainstream. Such an effect is here deemed the outcome of relational anti-systemness because it would be an effect caused by the fact that other media adapt to new conditions imposed by the mere existence and success of the new actor (in a long-term perspective, however, if such a development takes place on a large scale, it would, of course, cease to be controversial and, as a consequence, also lose its anti-system quality).

Considering these two dimensions in a $2 \times 2$ matrix, a framework appears that makes it possible to differentiate alternative media based on observations about the applicability of both notions. If a specific alternative media displays signs of ideological as well as relational anti-systemness, we can talk about "Anti-System alternative media" as in the upper left square in Figure 1. They position themselves (ideologically) in direct opposition to the traditional media standards and functioning (for example by deliberately not joining the National Press Club or the media ethical system, and by displaying antagonism towards mainstream media actors). Relationally, they also have a direct impact on the surrounding media landscape because other actors openly renounce them (polarization), which tends to entail coverage in mainstream media. The content is of such a nature that it: 1) represents a real competitive factor for mainstream media; and 2) would be problematic to publish within the framework of mainstream media because of its controversial nature. The combination of 1) and 2) means a possibility that they also affect the behavior of traditional media. For example, mainstream media may change their practices to avoid losing readers. In Sweden, the website nordfront.se-run by national socialist "Nordiska Motståndsrörelsen", or the "Nordic Resistance Movement" - is an example that shows signs of both ideological and relational anti-systemness. While being outspokenly and radically anti-system in the ideological sense, they have also managed to attract much attention from mainstream media actors, especially in relation to a number of widely covered marches, most notably the one performed close to and at the same time as the Göteborg Book Fair in 2017. Their presence caused much outrage and indignation from debaters who found it unacceptable to let them march at all. As an organization, the movement (with a few hundred activists in the organization) decidedly belongs to the marginal fringe, but their media outlet, nordfront.se has gained a lot of visibility from mainstream media coverage of their marches (for example, activists typically wear shields with the organization's web-address eye-catchingly printed on it; see, BBCWorld, 2017). The above-mentioned YouTube channel, Granskning Sverige, has also been the subject of much journalistic coverage.

If, however, only the criterion of ideological antisystemness is fulfilled and not the relational, as in the upper right square in Figure 1, they might be radical, hostile and antagonistic, but since they are generally ignored by other media, they can rightfully be described as "irrelevant", because they fail to elicit reactions and in effect publicity. They are not relationally anti-system in the sense that they have no direct impact on the surrounding media landscape. Their content is of a nature that would be problematic to publish within the framework of mainstream media. This category includes various blogs, social media accounts and other alternative media outlets run by fringe groups or individuals who simply do not cause any stir in the surrounding media environment. A good example is the Swedish PEGIDAmovement's Facebook page (Holt \& Haller, 2017). In Germany, PEGIDA's Facebook page has a large following (Haller \& Holt, 2018), and the movements activities have caused much debate and attracted prime time media coverage worldwide, but the Swedish branch has hardly been noted at all, and interactions around the rare posts appearing on the page are very few.

Moving down to the left corner square of the lower row of the matrix, we find alternative media that are not ideologically anti-system but have attributes of relational anti-systemness. These can be called "polarizing alternative media" and are not in principle (ideologically) opposed to the basic rules and guidelines that govern the established media's approach. They do not express a desire to replace the whole system, but call for changes in it. Those who take part in these media would not have problems connecting to the media ethical system and might actively seek membership in the National Press Club. However, the content is of such a nature that it: 1) competes with the established media; and 2) could be problematic to publish within the framework of the traditional media publishing channels. Their interpretation and application of the ethical guidelines are different from those of editors and journalists in traditional media, but do not challenge the existing order. Relationally, polarizing alternative media affect the surrounding media landscape in the same way as the anti-systemic - that is, by mutual rejection and open antagonism (for example they might not be accepted as members in the National Press Club, because Club members might find the "distant spatial location" too "distant". Secondly, they could also in theory affect other media's behavior. An example from the Swedish scene here would be the blog Samhällsnytt (formerly Avpixlat.info), a well-known ICAM in Sweden. One of the main contributors, Mats Dagerlind, applied for membership in the Press Club, but was denied entrance (Sköld, 2013) due to the fact that the blog did not have an official publisher, which is a criterion for being accepted as member in club.

The lower right corner of the table is a residual category for alternative media that do not meet any of the criteria for anti-systemness. This category is important in the context of discussing alternative media with agendas that are deemed as provocative and even harmful by some, but do not qualify for any of the two notions of anti-systemness presented in Figure 1. 


\section{Concluding Remarks}

The typology outlined in The Alternative Media Antisystemness Matrix can be useful both for selecting relevant cases when studying alternative media and for analyzing them. According to what has been described above, it will be of special interest to look specifically at purely "Anti-system" alternative media, with a potency to have a significant impact on public discourse and "polarizing alternative media", which might not pose a threat to the existing system per se, but still affect the debate, polarizing and presenting alternative agendas and interpretations of events to such an extent that meaningful discussions are difficult. Both types in the left-hand column can theoretically also have an impact on traditional media's behavior. "Irrelevant alternative media" can be represented by numerous blogs and sites that present views that are radically anti-system, but which do not cause any reactions from other actors or pose any threat to either the power over how reality is described or traditional media's circulation/readership. Such sites exist in abundance but fail to have any notable impact. Research about "alternative media" along these lines has largely been absent among media scholars but provides a good framework for distinguishing different alternative media from each other in a meaningful way and also lays the ground for relevant comparisons to be made between different cases.

The main aim of this article has been to offer a framework for analyzing alternative media that does not depend on any specific ideological position or normative assumption about the general nature of alternative media. Since media constitute the platform through which citizens in democratic society orient themselves and form opinions in order to participate in democratic life in an enlightened manner, the most important question to ask in relation to alternative media is how they might affect the conditions for public discourse. If they show signs of anti-systemness (either relational or ideological, but most potently both). They merit further scrutiny along lines of inquiry that seek to establish the magnitude of their possible anti-system effect on public discourse.

This framework also offers a fruitful way of putting specific cases in perspective and avoiding generalizations. While the purely anti-system alternative media can be described as both radical and threatening to a free and open debate and having a considerable impact on public discourse in terms of managing to attract a lot of attention, they might also be rather rare. More common are probably examples of extreme and fringe alternative media that live their lives mostly unnoticed by the vast majority and without opportunities of staging events or quasi-events that reward them with attention disproportionate to their size. In other words, mainstream media might actually turn otherwise irrelevant alternative media into full-fledged anti-system alternative media by the amount of coverage they devote to them. In cases where provocations are laid out as bait, this has proven to be a successful strategy (and a signum) for some alt-right actors (Gourarie, 2016).

It should also be noted that the matrix in Figure 1. can never be used in a static way-it is designed to allow for the dynamic nature of public discourse through media. Since the positions described in it are in essence dependent on other actors (mainstream media) and their positions, any momentary snapshot of the media landscape may become outdated after a while. Positions may have changed on both sides (ICAM and mainstream media). For example, an ICAM which falls under the category "polarizing alternative media" at one point might, due to changed behavior, increased acceptance from other actors or normalization of their worldview due to a changed political reality, verge into the category "Not anti-system". Nevertheless, the matrix remains a framework in which it is possible to make important distinctions between specific alternative media at any given time.

\subsection{Limitations and Future Research}

The contribution of this article is mainly theoretical, and the framework presented is intended to inspire future, more empirically oriented research. The examples mentioned above from the Swedish scene are included as illustrations, but in order to come to more valid conclusions, more rigorous empirical analysis of reach, impact and reactions from other media, as well as of attitudes and ideology needs to be done. Also, the argument made in this article does not purport to give the full answer to the question of how alternative media impact and affect public discourse-it highlights specific aspects of this, namely that the relational aspects, alongside the ideological aspects of the emergence of new alternative media actors are important for understanding the bigger picture.

\section{Conflict of Interests}

The author declares no conflicts of interest.

\section{References}

Anderson, C. W., \& Revers, M. (2018). From counterpower to counter-Pepe: The vagaries of participatory epistemology in a digital age. Media and Communication, 6(4), 24-35.

Atkinson, J. D., \& Leon Berg, S. V. (2012). Narrowmobilization and Tea Party activism: A study of right-leaning alternative media. Communication Studies, 63(5), 519-535. https://doi.org/10.1080/ 10510974.2011.649442

Atton, C. (2006). Far-right media on the internet: Culture, discourse and power. New Media \& Society, 8(4), 573-587. https://doi.org/10.1177/ 1461444806065653

Atton, C. (2015). The Routledge companion to alternative and community media. New York, NY: Routledge. 
Bailey, O., Cammaerts, B., \& Carpentier, N. (2007). Understanding alternative media. London: McGraw-Hill Education.

Barbaro, M. (2016). How did the media-how did weget this wrong? The New York Times. Retrieved from www.nytimes.com/2016/11/09/podcasts/electionanalysis-run-up.html

BBCWorld. (2017). Clashes at Swedish neo-Nazi rally. $B B C$. Retrieved from www.bbc.com/news/worldeurope-41454707

Burman, E. (2017). Krönika: Granskning Sverige blev för mycket-Även för Facebook [Granskning Sverige became too much-even for Facebook]. Ekuriren. Retrieved from www.ekuriren.se/ nyhetskronikor/granskning-sverige-blev-for-mycketaven-for-facebook

Borgs, M. (2015). Alternativa medier vs public service. Medium. Retrieved from medium.com/@martin borgs/alternativa-medier-public-service-ea3110e38 $4 \mathrm{ec}$

Capoccia, G. (2002). Anti-system parties: A conceptual reassessment. Journal of Theoretical Politics, 14(1), 9-35.

Chomsky, N. (1997). What makes mainstream media mainstream. Z Magazine, 10(10), 17-23.

Deuze, M., Bruns, A., \& Neuberger, C. (2007). Preparing for an age of participatory news. Journalism Practice, 1(3), 322-338. https://doi.org/10.1080/ 17512780701504864

Domingo, D., Quandt, T., Heinonen, A., Paulussen, S., Singer, J. B., \& Vujnovic, M. (2008). Participatory journalism practices in the media and beyond: An international comparative study of initiatives in online newspapers. Journalism Practice, 2(3), 326-342. https://doi.org/10.1080/17512780802281065

Downey, J., \& Fenton, N. (2003). New media, counter publicity and the public sphere. New Media \& Society, 5(2), 185-202. https://doi.org/10.1177/ 1461444803005002003

Downing, J. D., Ford, T. V., Gil, G., \& Stein, L. (2001). Radical media: Rebellious communication and social movements. London: Sage.

Ekman, M., \& Widholm, A. (2014). Politicians as media producers. Journalism Practice, 9(1), 78-91. https://doi.org/10.1080/17512786.2014.928467

Gourarie, C. (2016). How the 'alt-right' checkmated the media. Columbia Journalism Review. Retrieved from www.cjr.org/analysis/alt_right_media_clinton_trump. php

Haller, A., \& Holt, K. (2018). Paradoxical populism: How PEGIDA relates to mainstream and alternative media. Information, Communication \& Society, 1-16. https://doi.org/10.1080/1369118X.2018.1449882

Hellström, A., \& Nilsson, T. (2010). 'We are the good guys': Ideological positioning of the nationalist party Sverigedemokraterna in contemporary Swedish politics. Ethnicities, 10(1), 55-76. https://doi.org/ $10.1177 / 1468796809354214$
Holt, K. (2016a). "Alternativmedier"? En intervjustudie om mediekritik och mediemisstro ["Alternative media"? An interview study about media criticism and media distrust]. In L. Truedson (Ed.), Migrationen $i$ medierna: Men det får en väl inte prata om? (pp. 113-149). Stockholm: Institutet för mediestudier.

Holt, K. (2016b). Journalistik bortom redaktionerna [Journalism beyond the newsrooms]? In O. Westlund (Ed.), Människorna, medierna \& marknaden. Medieutredningens forskningsantologi om en demokrati i förändring (pp. 403-428). Stockholm: Wolters Kluwer.

Holt, K. (2017). Media distrust: A left-wing or right-wing specialty? Historical perspectives on today's debate about populism and the media. Paper presented at the symposium Perspectives on Right-Wing Populism and the Media: Scholarship, Journalism, Civil Society. Munich: Center for Advanced Studies (CAS), LMU Munich, Germany.

Holt, K., \& Haller, A. (2017). What does 'Lügenpresse' mean? Expressions of media distrust on PEGIDA's facebook pages. Politik, 20(4), 16.

Jenkins, H. (2008). Convergence culture: Where old and new media collide. New York, NY: New York University Press.

Kobayashi, T., \& Ikeda, K. I. (2009). Selective exposure in political web browsing: Empirical verification of 'cyber-balkanization' in Japan and the USA. Information, Communication \& Society, 12(6), 929-953. https://doi.org/10.1080/13691180802158490

Leung, D. K., \& Lee, F. L. (2014). Cultivating an active online counterpublic examining usage and political impact of internet alternative media. The International Journal of Press/Politics, 19(3), 340-359.

Lievrouw, L. (2011). Alternative and activist new media. Cambridge: Polity.

Mudde, C. (2014). Fighting the system? Populist radical right parties and party system change. Party Politics, 20(2), 217-226. https://doi.org/10.1177/ 1354068813519968

Nagle, A. (2017). Kill all normies: Online culture wars from 4chan and Tumblr to Trump and the alt-right. Winchester: Zero Books.

Newman, N., Fletcher, R., Kalogeropoulos, A., Levy, D. A. L., \& Kleis Nielsen, R. (2018). Reuters institute digital news Report 2018. Retrieved from: https:// reutersinstitute.politics.ox.ac.uk/sites/default/files/ digital-news-report-2018.pdf

O'Reilly, T. (2005). What is web 2.0? Design patterns and business models for the next generation of software. O'Reilly. Retrieved from oreilly.com/web2/ archive/what-is-web-20.html

Pajnik, M., \& Downing, J. D. (2008). Alternative media and the politics of resistance. Ljubljana: Peace Institute.

Penney, J., \& Dadas, C. (2014). (Re)Tweeting in the service of protest: Digital composition and circulation in the Occupy Wall Street movement. New Media \& Society, 16(1), 74-90. 
Pressens Samarbetsnämnd. (2001). Code of ethics for press, radio and television in Sweden. Pressens Samarbetsnämnd. Retrieved from po.se/about-thepress-ombudsman-and-press-council/code-of-ethics -for-press-radio-and-television-in-sweden

Quandt, T. (2018). Dark participation. Media and Communication, 6(4), 36-48.

Rauch, J. (2015). Exploring the alternative-mainstream dialectic: What "alternative media" means to a hybrid audience. Communication, Culture \& Critique, 8(1), 124-143. https://doi.org/10.1111/cccr.12068

Sartori, G. (2005). Parties and party systems: A framework for analysis. Colchester: ECPR press.

Sartori, G. (1976). Parties and party systems. Cambridge: Cambridge University Press.
Sköld, J. (2013). Avpixlats huvudman nekas medlemskap i Publicistklubben [Avpixlat's front figure denied membership in the Press Club]. Aftonbladet. Retrieved from www.aftonbladet.se/nyheter/article 16527633.ab

Sunstein, C. R. (2007). Republic.com 2.0. Princeton, NJ: Princeton University Press.

Truedson, L. (Ed.). (2016). Migrationen i medierna: Men det får en väl inte prata om [Migration in the media: But we are not allowed to talk about that, right]? Stockholm: Institutet för mediestudier.

Tsfati, Y. (2003). Media skepticism and climate of opinion perception. International Journal of Public Opinion Research, 15(1), 65-82.

\section{About the Author}

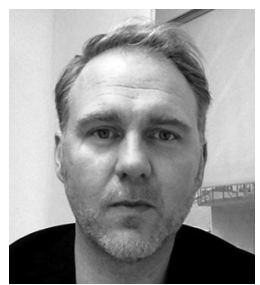

Kristoffer Holt is Associate Professor in Media and Communication Studies at the Department of Mass Communication and Media, Gulf University for Science and Technology, Kuwait. Holt has done research into alternative media, media criticism, media ethics and participatory journalism. His work has appeared in New Media \& Society, the European Journal of Communication, Information, Communication \& Society, Journalism Practice, Javnost: The Public and the Journal of Media Ethics, among others. 